\title{
6. The Invention of Tradition and the Representation of Russian Monarchy
}

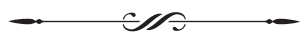

$t$ the conclusion of Paul Miliukov's lectures at the University of Chicago A in 1903, he declared that Russia had no "real political tradition." The old political traditions had been destroyed by Peter the Great and "could not possibly be renewed." The existing system owed its solidity "not so much to any tradition as to the force of inertia, and to such multiform and numerous measures that the autocracy has been obliged to take in self-defense." Miliukov contrasted Russia's experience to Japan's, which he had learned of from the lectures of a Professor Ienaga at the same university. In Japan, Miliukov argued, the rapidity of change during the Meiji restoration had allowed old traditions to survive and "to enter into some degree of combination with the elements of the new life and culture."

We now know, from the work of T. Fujitani and Carol Gluck, that these presumably old Japanese traditions had been ingeniously contrived by a modernizing elite in the second half of the nineteenth century. Indeed, Fujitani provides a systematic account of the creation of such imperial ceremonies, images, and forms of ritual behavior during the Meiji restoration. ${ }^{2}$ Fujitani and Gluck have traced the process of "the invention of tradition" that Eric Hobsbawm memorably defined as an object of historical study and investigated in his path-breaking book by that name. Hobsbawm focused on the social and political contexts that prompt the invention of new traditions, which "where possible ... attempt to establish continuity with a suitable

1 Paul Miliukov, Russia and Its Crisis (New York: Collier Books, 1962), 400-03.

2 T. Fujitani, Splendid Monarchy: Power and Pageantry in Modern Japan (Berkeley: University of California Press, 1996); Carol Gluck, Japan's Modern Myths. 
historic past." 3 David Cannadine developed the concept in relationship to British monarchy by detailing the invention of a tradition of pomp and magnificence in the late Victorian era. ${ }^{4}$

But for invented traditions to take hold there must be an inclination to receive them-a belief in certain overarching fictions they sustain. The study of "the invention of tradition" often ignores the symbolic context of the continuities these traditions are supposed to establish. Thus, Hobsbawm and Cannadine discuss the adoption of the Gothic style in nineteenth-century England, but do not suggest why the Gothic style was chosen. The meaning of invented traditions can be understood only within the context of the mythical narratives that served as their referents. It is notable that in both the British and Japanese case, the monarch represents something more than a ruler: he or she is a symbol of national unity and grandeur that is not dependent on the exercise of political power. The invention of tradition proceeded in a symbolic context that presumed a separation of the act of ruling from the symbolic preeminence of the monarch.

British ceremonial innovation took place under a monarchy that had represented the popular focus of nation and empire at least since the eighteenth century.5 Vernon Bogdanor wrote, "most of us surely have always understood in our bones, that we remain a profoundly monarchical nation." In Japan, the emperor had long represented the bearer of a symbolic supremacy untainted by the demeaning obligations of exercising power, fulfilled instead by high figures in the elite. ${ }^{7}$ The Prussian and Hapsburg monarchs in the nineteenth century broadened their popular support by de-emphasizing but not eliminating the attributes of political power in their public image.

In Russia, the symbolic preeminence of the emperor had always been closely linked with the extent and efficacy of monarchical power. The sophis-

3 The Invention of Tradition, ed. Eric Hobsbawm and Terence Ranger (Cambridge: Cambridge University Press, 1983), 1-2.

4 David Cannadine, "The Context, Performance and Meaning of Ritual: The British Monarchy and the 'Invention of Tradition,' c. 1820-1977," in Hobsbawm and Ranger, eds., The Invention of Tradition, 101-64.

5 Linda Colley, "The Apotheosis of George III: Loyalty, Royalty and the British Nation 1760-1820," Past and Present, No. 102 (February 1981): 94-129.

$6 \quad$ Cited in The New York Times, June 5, 2002, 12.

7 John Whitney Hall, “A Monarch for Modern Japan," in Robert E. Ward, ed., Political Development in Modern Japan (Princeton: Princeton University Press, 1973), 11-64. 
ticated distinction between the "body-mortal," and the "body-politic," which was made to a greater or lesser degree in the absolute monarchies of the West, did not take hold in Russia. ${ }^{8}$ Russian monarchs themselves had to display the transcendent features of the political order in performances constantly reaffirming the superhuman, heroic attributes attached to the state. Myth and ceremonies elevated the monarch above the population as a distant and legitimate sovereign. I have called the particular realizations of the governing myth by the successors to the throne "scenarios of power." The scenarios cast each ruler as a mythic hero, transforming the myth to fit his or her personal views and tastes, as well as the cultural and political circumstances of the time. Rhetoric and iconography evoked a transcendent persona endowed with the features idealized in the scenario.

The representation of Russian monarchy appears as a succession of apparent ruptures, producing an illusion of constant renewal, prodigies of transformation effected by the irresistible power of the monarch's will. The political threats posed by nineteenth-century revolutionary movements and increasing governmental role of bureaucratic institutions produced only more demonstrative affirmations of the ruler's prerogatives. The godlike image carried a mystique of its own: the office of a Russian emperor without unlimited authority was unthinkable and intolerable for the individual ruler, regardless of expedience or principle.

The definition of power precluded political participation, even of the highest, most conservative layers of society. English monarchs preserved their symbolic preeminence while withdrawing from the exercise of political power. In Japan, the governmental elite fashioned a popular monarchy by introducing a representative system that comprised only 1.1 percent of the population. In Germany and the Hapsburg Empire a limited suffrage was the basis of parliamentary institutions that the emperor and his ministers could dominate. Russian emperors repeatedly rebuffed proposals to co-opt even the most conservative supporters of the political status quo and allow limited participation in government. While this intransigence is explained in part by the fear that concessions would begin the erosion of monarchical power observed in France, it had deeper roots in the culture of Russian monarchy. The authority of the emperor derived from his symbolic preeminence and distance

8 Ernst H. Kantorowicz, The King's Two Bodies, 383-450; Michael Cherniavsky, Tsar and People, 86. 
from his subjects and could founder if compromised. For example, Alexander II oversaw the emancipation of the Russian serfs and sweeping reforms of local government and the court system, which involved consultation with members of the nobility. However, though he received proposals for limited participation in government, he never relented in his belief that only the monarch could transcend the separate interests of the estates and direct the formulation of policies. In 1865, he refused to receive the address of the Moscow gentry calling for a popular assembly to consist of gentry representatives. He declared, "To none of [my subjects] is it allowed to give prior notice to MY incessant care for the well being of Russia, or to decide beforehand questions about the basic principles of her state institutions. No class has the right to speak in the name of other estates. No one is called to take it upon himself to petition me about the general good and the needs of state." 9

The myths of Russian monarchy set the ruler above the noble and imperial elites by evoking a power derived from God, but elevated by the foreign sources of his authority. His image was derived from beyond the seas, from the Vikings, from the Byzantine emperor, from Roman and western rulersIvan IV boasting of his descent from Riurik, the legendary founder of Russia, declared that he was no Russe. Tsar Alexei Mikhailovich in the seventeenth century presented himself in Byzantine robes and adopted ceremonies meant to follow those of the Byzantine emperor. With Peter the Great the image became Western, as he took on the Roman models of Western Europe and cast himself as Imperator.

My point here is not about the practice of borrowing, since borrowing of features and signs characterizes many if not all monarchies. Rather it is that in Russia the act of borrowing itself became an attribute of power. The appropriation of the attributes of foreign exemplars of sovereignty elevated the ruler and his servitors above the Russians and other subject peoples of the empire. A second, and for us particularly germane, characteristic was an imperative to demonstrate change from previous presentations or scenarios of power. Beginning with Peter the Great, the power to transform-to show himself unbound by traditions of the previous reign, but to eliminate its abuses, and reverse its failures-was a sign of his absolute power. Peter the Great, Georges Florovsky wrote, "was inclined to exaggerate everything new. He wanted

$9 \quad$ Terence Emmons, The Russian Landed Gentry and the Peasant Emancipation of 1861 (Cambridge: Cambridge University Press, 1968), 411. 
everything refurbished and altered until it passed beyond all recognition."10 It did not matter whether the changes represented true innovations or not; it was the appearance of change that was important, for the signs of renovation revealed the transformative powers of the Russian emperors and empresses.

Each scenario repeated the Petrine cadence, opening with energetic demonstrative change, a discrediting, explicit or implicit of the predecessor, a new vision of the creative perspective of the autocrat. Each reign, except the last, undertook a symbolic repudiation of the previous one, an assertion of the transcendent image of a ruler not limited by the examples or legacy of his or her predecessors. In the nineteenth centuries this dynamic of repudiation continued, though it was tempered with assertions of dynastic continuity and devotion to a national heritage. Leo Tolstoy observed this pattern early in the reign of Alexander II. He remarked, "Alexander II came to the throne and as always happens the new reign began to act in a spirit contrary to his predecessor [sic]." 11 The invention of tradition-making the new appear as if it were old-took place in Russia under the symbolic imperative that the old appear new. New traditions had to occasion a break with the past in order to create a different conception of the past more suited to the cultural and political needs of the contemporary monarchy. Miliukov, like most members of the liberal intelligentsia, regarded these traditions as flim-flam generated by a doomed monarchy. The traditions of Russian monarchy, it is true, failed to unite government and society, but they did provide rationales for the preservation of absolutism in Russia.

In nineteenth-century Russia, the invention of traditions strove to make the monarchy appear national. The westernized monarchy, which since Peter's reign was at pains to display its European character, now sought instead to display distinctive native traits that would ensure that it would not follow the fatal course of its counterparts. The emperors who succeeded the throne after the revolutionary threats of 1825 and 1881-Nicholas I and Alexander IIIpresented images that distanced themselves from the European goals, images, and policies that were associated with their predecessors. To this end, they

10 Georges Florovsky, Ways of Russian Theology (Belmont, MA: Nordland, 1979) 1:114.

11 Cited in Kathryn B. Feuer, Tolstoy and the Genesis of War and Peace (Ithaca, NY: Cornell University Press, 1996), 150. 
sought to establish traditions that would link them with the Russian people, without, however jeopardizing the distance that ensured their symbolic preeminence.

The statements in the months following Nicholas I's accession explained the failure of the Decembrist uprising by the innate loyalty of the Russian people to their rulers. The manifesto on the sentencing of the Decembrist revolutionaries, issued on July 13, 1826, disclosed a new grounding for imperial authority. The Decembrists' design to introduce western constitutional institutions, the manifesto stated, was alien to the Russian people. "In a state where love for monarchs and devotion to the throne are based on the native characteristics of the people, where there are laws of the fatherland and firmness in administration, all efforts of the evil-intentioned will be in vain and insane." 12 The emperor no longer appeared as a remote and supernal figure, the philosopher king, whose authority was justified by the supreme reason he brought to bear on institutions for the benefit of his people. Rather, he was presented as the object of the people's devotion, making the monarchy appear grounded on a tacit popular mandate.

The love of the people thus justified the westernized monarch's power. In the first decade of Nicholas's reign, this relationship was consecrated, or reified, in an idea of absolute monarchy expressed in the word "autocracy" (samoderzhavie). The idea, projected into the past, became the dominant motif of official history. A lecture, delivered in 1832 in the presence of the then Assistant Minister of Education, Sergei Uvarov, by Mikhail Pogodin provided the regime's tale of origin: "The Varangians came to us, but voluntarily chosen, at least from the start, not like Western victors and conquerors-the first essential distinction in the kernel, the seed of the Russian State in comparison with other Europeans." ${ }^{3}$ Uvarov's famous memorandum of 1833 provided an ideological formulation of these ideas, announcing the slogan-Orthodoxy, Autocracy, and Nationality. Autocracy was clearly the central element of Uvarov's triad. He wrote, "autocracy constitutes the main condition of the political existence of Russia... The saving conviction that Russia lives and is protected by the spirit of strong, humane, and enlightened autocracy must permeate popular education and must develop with it."14

12 N. K. Shil'der, Imperator Nikolai Pervyi, 1: 704-06.

13 M. P. Pogodin, Istoriko-kriticheskie otryvki (Moscow: Semen, 1846), 6-8.

14 Cited in Nicholas Riasanovsky, Nicholas I and Official Nationality in Russia, 18251855 (Berkeley: University of California Press, 1959), 74-75. 
It was in this context that new traditions appeared showing the emperor's absolute power to be a historical expression of Russia's national heritage. Here I will discuss two of these invented traditions: new forms of presentation at the Russian coronation, and what was conceived as native styles of Russian church architecture. Both contributed to the performance of a national narrative that showed the common past uniting the emperors with their Russian subjects.

The coronation of Nicholas I in 1826 marked this change of the meaning of Russian imperial coronations. It consecrated both the idea of absolute monarchy and the ruling dynasty as expressions of the idea of nation. The most important innovation took place at the conclusion of the coronation ceremonies. After the recessional to the Archangel and Annunciation Cathedrals, Nicholas ascended the Red Staircase before the Palace of Facets, turned to the crowd, and bowed three times, to their thunderous Hoorahs! The triple bow showed the emperor's response to the people's acclaim. It was an unprecedented sign of a reciprocity of feeling, a signal expression of the ruler's bond with the people, marking a breach of the imagery of Olympian distance. It aroused the indignation of the tsar's younger brother, the Grand Duke Michael Pavlovich, who did not think it befitting of an emperor. ${ }^{15}$ In subsequent decades, the triple bow from the Red Staircase became a central ceremony of Russian autocracy, whenever the emperor visited Moscow. (Figure 1) By the end of the century, it was customarily described as an "ancient tradition." 16

The creation of a national style of church architecture expressed another theme of official nationality-the historic bond between the autocracy and the Russian Orthodox Church. Nicholas I and Alexander III looked to prePetrine models to build contemporary artifacts of a Russian national past. To meet their sovereigns' expectations, official architecture had to create a national architecture from multifarious Byzantine and indigenous styles. Constantine Thon, a young architect of German-Russian extraction, answered Nicholas's wish for a national architecture when his project for the St. Catherine's Church in St. Petersburg suggested the five-cupola form of the Vladimir and Moscow Assumption Cathedrals. A decree of March 25, 1841 ordained that "the taste of ancient Byzantine architecture should be preserved, by preference and as far as is possible" in the construction of Orthodox churches. "The drawings

15 Cherniavsky, Tsar and People, 148-49.

16 Scenarios of Power, 1: 290-92. 


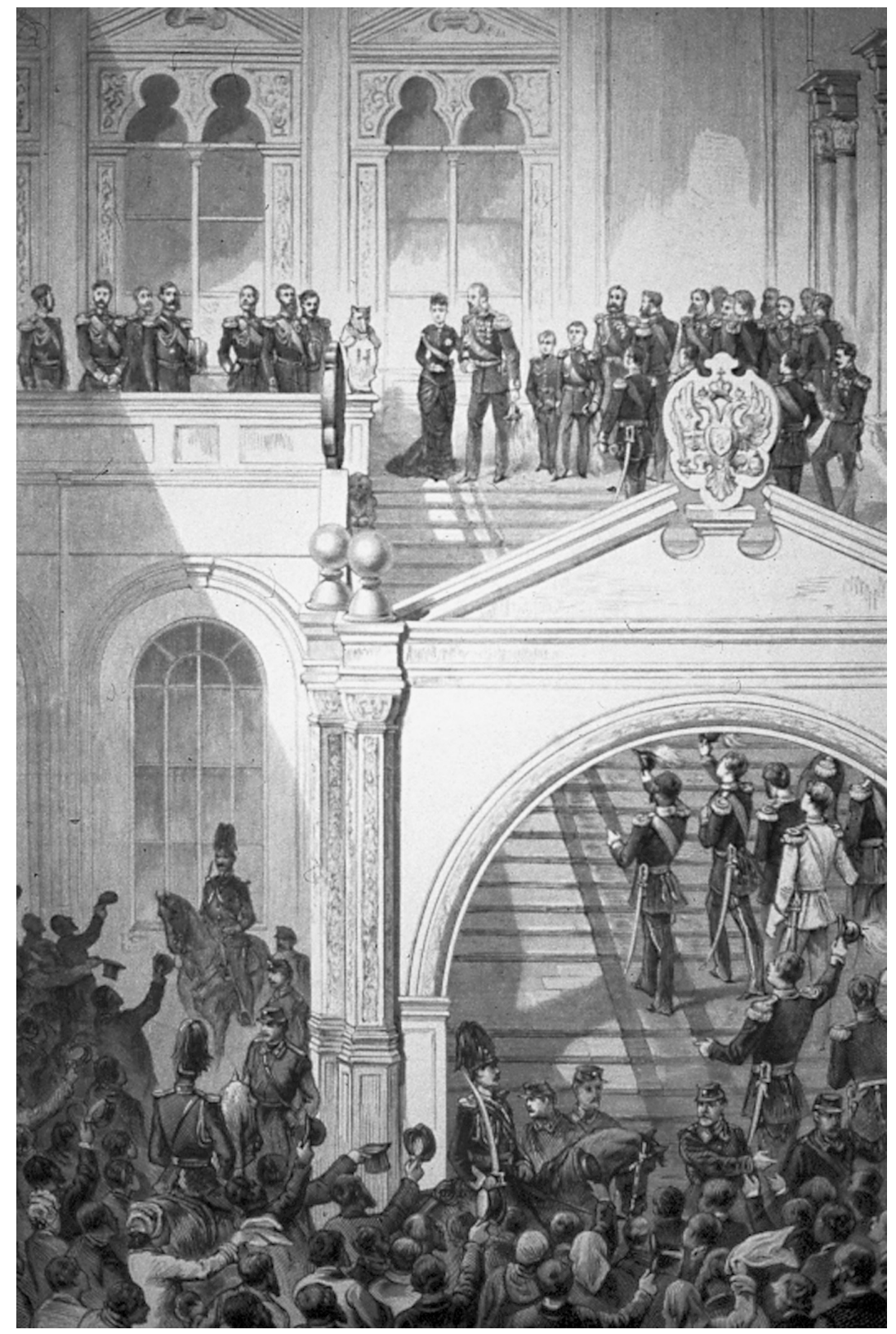

Figure 1.

Alexander III Bows to the People From the Red Staircase, July 17, 1881. Lithograph, Vsemirnaia Illiustratsiia, No. 656 (1881) 
of Professor Constantine Thon composed for the construction of Orthodox churches may prove useful in this regard."17

Thon's architectural projects typify the nineteenth-century tendency to use architecture to present a historical narrative, in this case the adoption of Byzantine forms of monarchy and culture in early Rus'. Thon grafted the five-cupola form of the Assumption Cathedrals in the Moscow Kremlin and Vladimir onto a nineteenth-century neoclassical structure, expressing the eclectic spirit of Nicholas's official-nationality doctrine, which, while claiming national distinctiveness, sought to defend the western cultural and institutional heritage. ${ }^{18}$ Its most prominent example was the massive Cathedral of Christ the Redeemer in Moscow (1837-1882), built to commemorate Russia's victory over Napoleon in 1812.19 While the proportions, the arcades, and the structure of the cupolas of the cathedral were typically neoclassical, the exterior decorative elements asserted the building's Russian character by recalling the architecture of the fifteenth century. ${ }^{20}$ The Redeemer Cathedral set the pattern for similar churches that would provide specific visual references to both the national past of autocracy and the universalistic context of empire derived from Byzantium. Published explanations of the buildings spelled out these references, disclosing the meaning of Russia's architectural heritage to all. The Redeemer Cathedral was regarded in the nineteenth century as cumbersome and something of an eyesore on the Moscow landscape. It was razed in 1931-1932, but it retained its national associations and has recently been reconstructed at its site in the center of Moscow. ${ }^{21}$ (See Figure 1 in Article 8).

17 Svod zakonov rossiiskoi imperii, (St. Petersburg: Tip. II Otd. Sobstvennoi E.I.V. Kantseliarii 1857), 12: 49. The provision is article 218 of the Stroitel'nyi Ustav.

18 E. A. Borisova, Russkaia arkbitektura vtoroi poloviny XIX veka (Moscow: Nauka, 1979), 100, 101; Konstantin Ton, Tserkvi, sochinennye arkbitektorom Ego Imperatorskogo Velichestva Professorom Arkhtektury Imperatorskoi Akademii Khudozhestv $i$ chlenom raznykh akademii Konstantinom Tonom (St. Petersburg: n.p, 1838).

19 The most thorough treatment of the history of the building is E. Kirichenko, Khram Khrista Spasitelia $v$ Moskve (Moscow: Planeta, 1997).

20 Ibid., 61-63; Borisova, Russkaia arkbitektura, 106-09.

21 See the perceptive comments of Svetlana Boym, who sees the rebuilding as one episode in the "obliteration of memory" that proceeded after the collapse of the Soviet Union. She cites the words of "a middle aged man with wistful eyes" in a tourist advertisement, "Don't divide Russian into past and present. Russia is one." Svetlana Boym, The Future of Nostalgia (New York, Basic Books, 2001), 100-08. 
The assassination of Alexander II occasioned an even sharper symbolic break-a blanket repudiation of the westernizing tradition of the autocracy and the adoption of a new historical myth. If the official nationality located the nation in the Russian people's worship of their western overlords, the new myth presented the emperor as ethnically and religiously one with his people, as the most Russian of Russians. The program of Alexander III's reign was set forth in the manifesto of April 29, 1881, written by Alexander III's mentor and closest advisor, Constantine Pobedonostsev. Reaffirming the principle of autocracy, Pobedonostsev evoked a new founding period of the Russian empire in an idealized vision of seventeenth-century Muscovy. The words "zemlia russkaia," Russian land, conjured a Slavophile picture of the unity of all estates in Russia, a single people, living in harmony with their tsar. The Russian land had been disgraced by vile sedition, but "hereditary tsarist power," continued to enjoy the love of its subjects, and this power "in unbreakable ... union with Our land" had survived such troubles_smuty -in the past. The people displayed their devotion to the tsar through prayers in the Orthodox church. These prayers brought divine blessings on the sovereign.

Alexander III's coronation in 1883, and that of Nicholas II only thirteen years later, expressed not the merger of the Western and Russian polarities of imperial culture, but a coming home: a denial of polarities and a celebration of the national character of the Russian emperor. The rhetoric of official and semi-official texts emphasized the organic and ethnic connections of the simple Russian people with their Russian tsar. The Pan-Slavist journalist and general Vissarion Komarov described the people of Moscow on May 15, the day of the coronation ceremonies, as "a vital force, concealing in itself the presence of God." He evoked a physical sense of the merger of people and sovereign. His key words were "splosh'," total, variants of the verb "splotit" to fuse, etymologically connected with the word used to describe binding longitudinal sections of wood. ${ }^{22}$

The post-coronation festivities evoked the dynasty's Muscovite past in art, poetry, and music, making a political idiom of le style russe. The seventeenthcentury interior of the Hall of Facets, with murals of Semen Ushakov, was restored for the coronation banquet by artists brought from the Palekh shop of

22 V. Komarov, $V$ pamiat' sviashchennogo koronovaniia Gosudaria Imperatora Aleksandra III i Gosudaryni Imperatritsy Marii Fedorovny (St. Petersburg: V. Komarov, 1883), 110. 
icon painters. The banquet menu, designed by the painter Victor Vasnetsov, in old Russian style showed a scene of boyars bearing the tsar's regalia to the feast; the reverse depicted a priest and peasants bearing bread and salt, and a player of the ancient gusliar' singing praise to the tsar. An orchestra performed Tchaikovsky's cantata, "Moskva," composed especially for the occasion. The libretto by the pan-Slavist poet Apollon Maikov presented the tsar as the epic Russian folk hero, the bogatyr' representing the hopes of all Slavic nations. The gala performance at Alexander II's coronation celebrations in 1856 was of Donizetti's opera bouffe, "L'Elisir d'Amore;" now it was the first and last scenes of Glinka's "Life for the Tsar," about a simple Russian peasant's sacrifice to save the newly chosen Michael Romanov in 1613. A chorus of nearly 800 singers, accompanied by musicians playing old horns, sang the Glory (Slav'sia) chorus as row after row of soldiers marched in to bring the opera, and presumably the Troubles of the early 1880 s, to a rousing close. ${ }^{23}$

In a letter to the empress Maria Fedorovna on the first anniversary of his coronation, Alexander III described it as a "great event for us. And it proved to a surprised and morally corrupt Europe that Russia is still the same holy, orthodox Russia as it was under the Moscow Tsars and, if God permits, as it will remain forever." ${ }^{24}$ Alexander sought to display the Muscovite character of imperial Russia by building Orthodox Churches in what he believed was a true Muscovite style. The building announcing the new official national style was the Resurrection Cathedral erected on the site of Alexander II's assassination, in popular parlance, "the Savior on the Blood."25

Michael Flier's articles on the planning, architecture, and iconography of the Resurrection Cathedral provide a remarkable glimpse of the process of the invention of tradition. ${ }^{26}$ The architects who participated in the initial competition did not understand the new scenario or its implications, and

23 Borisova, Russkaia arkhitektura, 307.

24 GARF, 642-1-709, 24-25. Letter of May 16, 1884.

25 For a more extended discussion of the revival churches see my article, “'The Russian Style' in Church Architecture as Imperial Symbol after 1881," in Architectures of Russian Identity: 1500 to the Present, ed. James Cracraft and Dan Rowland (Ithaca, NY: Cornell University Press, 2003), 101-116; Scenarios, 2, 244-56.

26 Michael S. Flier, "At Daggers Drawn: the Competition for the Church of the Savior on the Blood," in For SK: In Celebration of the Life and Career of Simon Karlinsky, ed. Michael S. Flier and Robert P. Hughes (Berkeley: University of California Press, 1994), 97-115. 
drafted their plans in Thon style. Alexander, not one to temper his opinions, rejected them all. He insisted that he wanted the church to be in "Russian style," and "in the style of the time of the Muscovite tsars of the seventeenth century," 27 without indicating precisely what he had in mind. The project that won the tsar's approval was submitted by Father Ignatii, the abbot of the Trinity-Sergeev Hermitage at Peterhof. Ignatii, who had briefly studied at the Academy of Arts, drew the sketch of the church, he claimed, "almost automatically," on the day of Annunciation. But he was not a professional architect, and his plans had to be completely revised by the architect Alfred Parland. The final form of the cathedral, Michael Flier has shown, was a mélange of the plans of many architects who were struggling to find a seventeenth-century national style that suited the emperor's taste. ${ }^{28}$ The decision to depart from the classical Moscow-Vladimir style was clearly the emperor's. Although the church was built on the basis of public donations, the imperial family donated nearly one-quarter of the 4.6 million ruble cost. Alexander continued to watch over the completion of the cathedral and resisted proposals to economize. ${ }^{29}$

The example Alexander III had in mind was St. Basil's cathedral on Red Square in Moscow, and the project designed by Alfred Parland, presumably on the basis of Ignatii's sketches, recalled St. Basil's cathedral (see Article 8, Figure 2). The flamboyant exterior decoration-the devices of kokoshniki, and shirinki, the tent roof, and onion cupolas-set the church apart from the Thon model and evoked a different historical narrative. However, Boris Kirikov has shown that the new church's five-cupola cruciform structure, with a large central basilica-like hall, has little in common with the intricate warren of Vasilii the Blessed, and the decorative elements borrow from a great number of seventeenth century churches in the Moscow-Iaroslavl style. ${ }^{30}$

27 In April, 1882, the mayor of St. Petersburg informed the City Duma that he had received notification from the St. Petersburg Governor that the Minister of the Interior had conveyed the tsar's wish that the cathedral be built "in Russian style." Moskovskie Vedomosti, April 9, 1882; A. A. Parland, Khram Voskresenie Khristova sooruzhennyi na meste smertel'nogo poraneniia $v$ Boze pochivshego Imperatora Aleksandra II na ekaterinskom kanale v Sankt-Peterburge (St. Petersburg: n.p., 1909), 2.

28 Michael S. Flier “At Daggers Drawn,” 109-11.

29 Iu. V. Trubinov, Khram Voskreseniia Khristova [Spas na Krovi] (St. Petersburg: Beloe i Chernoe1997), 33, 54, 94.

30 B. M. Kirikov, "Khram Voskreseniia Khristova (k istorii russkogo stilia v Peterburge)," Nevskii Arkhiv: istoriko-kraevedcheskii sbornik 1 (1993): 230-33; I. Grabar', Istoriia Russkogo Iskusstva, Vol. 9, Book 2 (Moscow: n.p., 1965): 269. 
The theme of resurrection was central to Alexander III's scenario, which envisioned the rebirth of Russian monarchy after the troubled last years of his father's reign. Michael Flier has shown the predominance of the resurrection imagery in the church. The exterior mosaics depict the bearing of the cross, the Crucifixion, the Deposition, the Descent into Hell, and, on the Southern Pediment, Christ's Resurrection. He observed that the interior is modeled on the layout of the Church of the Holy Sepulcher in Jerusalem, also named "The Resurrection of Christ." The new cathedral thus places Russia’s beginning not at the Roman empire-as in the legends of Andrew the First-Called and Prus-or at Byzantium, as claimed in the legend of Monomakh, but at Golgotha itself, now with Christ's martyrdom transposed to Russia. ${ }^{31}$ The mosaics thus established Jerusalem as a new point of beginning for the sacred narrative of Russian monarchy and define Russia as possessing a sacred history, distinct not only from the west, but also from Byzantium.

The Resurrection Cathedral built on the site of Alexander II's assassination on Catherine Canal is easily visible from Nevskii Prospect. There is nothing understated in its appearance; it is a declaration of contempt for the order and symmetry of the capital, producing what Louis Réau, the noted French student of Russian art history, described as "a troubling dissonance." A prominent building in Moscow style set in the middle of classical Petersburg was meant to express this rejection. It was, Flier writes, "old Muscovy plunged into the heart of European Petersburg." 32 Although the cathedral was not consecrated until 1907 , its amalgam of the five-cupola form with pre-Petrine ornamentation became the dominant model for church design in the official Russian style, from 1881 to 1905. Pobedonostsev wrote in a report of the 1890s that Alexander himself reviewed projects for churches and "willingly approved those projects that reproduced the ancient tradition of Russian churches." 33 More than twenty official Russian style churches went up in St. Petersburg from 1881-1914. The Assumption Cathedral of the St. Petersburg branch of the Kiev Monastery of the Caves (1895-1900), looks out over the Neva from the

$31 \quad$ Michael S. Flier: "The Church of the Savior on the Blood; Projection, Rejection, Resurrection," in Christianity and the Eastern Slavs, ed. Michael S. Flier and Robert P. Hughes (Berkeley: University of California Press, 1994), 32-43.

32 Louis Réau, Saint Petersburg (Paris: H. Laurens, 1913), 67-68; Flier, "The Church of the Savior on the Blood," 30.

33 A. Iu. Polunov, Pod vlast'iu ober-prokurora: gosudarstvo i tserkov'v epokhu Aleksandra III (Moscow: AIRO-XX, 1996), 76. 
Nikolaevskii embankment, a five-cupola church with elaborate seventeenthcentury decoration. The Resurrection Cathedral on the Obvodnyi Canal (1904-08) within view of the Warsaw Railroad Station features a Byzantine central basilica, embellished with kokoshniki and a tent belfry characteristic of sixteenth and seventeeth century Russia. Nicholas Sultanov's Peter-Paul Cathedral at Peterhof, completed in the late 1890s, brought the images of the Resurrection Cathedral to the playground of the court. Set on a pond, it reproduced the tent forms and kokoshniki of the seventeenth century in brick, which Sultanov considered the building material most suitable for Russian churches. It was in stark contrast to the Rococo elegance of the Peterhof palaces.

Churches built in the provinces were also situated at prominent sites as means to edify or rebuke the population. ${ }^{34} \mathrm{~A}$ fanciful single domed Church of the Savior covered with kokoshniki and other decorations accompanied by a tent shape bell-tower went up at Borki near Kharkov, the site of the wreck of the emperor's train in 1888 , as a sign of miraculous salvation. ${ }^{35}$ Churches built near factories promoted efforts by the government and church to awaken the religious faith of industrial workers. At the beginning of the 1890s, Leontii Benois designed a church for 2,000 people near the textile factory of the Hofmeister, N. K. Nechaev-Maltsov, in the town of Gusev, near Vladimir. This massive edifice was surmounted by a great tent roof and bell tower at one end, and by cupolas and kokoshniki in the Iaroslavl style at the other. The image of St. George, the patron saint of Moscow, placed over the portal was probably the work of Victor Vasnetsov, who executed the paintings on the interior walls. A drawing of this church, which has been destroyed since, recalls the tent and cupola forms of Vasilii the Blessed. Fedor Shekhtel's large Church of the Savior in the textile center at Ivanovo-Voznesensk, completed in 1898, was built in neo-Byzantine style. ${ }^{36}$

As the last example suggests, the appearance of new forms did not rule out churches built in the previous style. Under Nicholas II, churches in the Thon

\footnotetext{
34 These edifices as well as others in the national style are discussed in V. G. Lisovskii, "Natsional'nyi Stil" v arkbitekture Rossii (Moscow: Sovpadenie, 2000), 197-211.

35 Niva, 24 (1894): 569.

36 Zodchii (1893): 8, Plates, 1, 2, 6, (1903), 30-31; William Craft Brumfield, The Origins of Modernism in Russian Architecture (Berkeley: University of California Press, 1991), 129.
} 
style arose along with those in the style of seventeenth century Muscovy. Competing traditions persisted, confusing the symbolic statement that the monarchy was strenuously trying to exert. ${ }^{37}$ In late imperial Russia, we observe a process of symbolic fragmentation that corresponds to the social fragmentation described in Alfred Rieber's model of a "sedimentary society," in which "successive social forms accumulated, each constituting a layer that covered all or most of society without altering the older forms lying under the surface." The invention of tradition in Russia sustained a myth requiring dramatic reversals and sharp discontinuities in order to reinforce an image of supreme and irresistible power. In this context, invented traditions hardly contributed to a sense of a unified historical past. To the critical eye of Paul Miliukov, the plethora of traditions appeared as equivalent to no tradition at all.

$37 \quad$ Alfred Rieber, "The Sedimentary Society," in Between Tsar and People: Educated Society and the Quest for Public Identity in Late Imperial Russia, ed. Edith Clowes, Samuel D. Kassow, and James L. West (Princeton: Princeton University Press, 1991), 361-63. 